\title{
Kebijakan Belt and Road Initiative (BRI) Tiongkok pada Masa Pemerintahan Xi Jinping
}

\author{
Syaiful Anam ${ }^{1}$, Ristiyani ${ }^{2}$ \\ ${ }^{1}$ Program Studi Hubungan Internasional, Universitas Mataram-NTB, \\ s.anam@unram.ac.id \\ ${ }^{2}$ Program Studi Hubungan Internasional, Universitas Mataram-NTB, \\ ristiyani333@gmail.com
}

\begin{abstract}
Belt and Road Initiative (BRI) is one of the ambitious economic policies issued during the reign of China Xi Jinping. BRI includes two aspects: the Silk Road Economic Belt and the 21st Century Maritime Silk Road. BRI is a gigantic project as it covers 2/3 of the global population and 3/4 of energy sources. This article tries to answer questions about why China issuing BRI policy by using the perspective of neorealism as a theory of international relations that includes the concept of national interest, the balance of power and hegemonic stability. The findings in this paper is divided into three premises, namely (1) the interest of China to secure supply lines of energy to the Middle East and Central Asia through cooperation with the countries in South Asia, (2) the ambition of China to take over the leadership role in Asia through the seizure of the fast train project financing with Japan, (3) China sought to challenge US both in Security and Economic fields. This paper is then expected to be used as a comparative material for similar studies and become contributions to the parties concerned.
\end{abstract}

Keywords: Belt and Road Initiative (BRI); China; National Interest; Leadership; Hegemony

\begin{abstract}
ABSTRAK
Belt and Road Initiative (BRI) merupakan salah satu kebijakan ambisius yang dikeluarkan Tiongkok pada masa pemerintahan Xi Jinping. BRI mencakup dua aspek yaitu the Silk Road Economic Belt dan the 21st Century Maritime Silk Road. BRI merupakan proyek raksasa yang dikeluarkan Tiongkok pada masa pemerintahan Xi Jinping karena mencakup 2/3 populasi global dan 3/4 sumber energi. Tulisan ini berusaha menjawab pertanyaan tentang mengapa Tiongkok mengeluarkan kebijakan BRI dengan menggunakan perspektif neorealisme yang terdiri dari konsep kepentingan nasional, balance of power, dan hegemonic stability. Hasil temuan dalam tulisan ini terbagi ke dalam 3 alasan, yaitu (1) kepentingan Tiongkok untuk mengamankan jalur pasokan energi ke Timur Tengah dan Asia Tengah lewat kerjasama dengan negara-negara di Asia Selatan, (2) ambisi Tiongkok mengambil alih peran kepemimpinan di kawasan Asia lewat perebutan pembiayaan proyek kereta cepat dengan Jepang, (3) Tiongkok berusaha menantang hegemoni AS baik itu di bidang keamanan maupun ekonomi. Tulisan ini selanjutnya diharapkan dapat dijadikan sebagai bahan komparatif bagi penelitian sejenis dan menjadi sumbangan pemikiran bagi pihak-pihak yang berkepentingan.
\end{abstract}

Kata Kunci: Belt and Road Initiative (BRI); Tiongkok; Kepentingan Nasional; Kepemimpinan; Hegemoni 


\section{Pendahuluan}

Selama tahun pertama menjabat sebagai Presiden Tiongkok, Xi Jinping mengeluarkan serangkaian kebijakan ekonomi yang ambisius. Salah satu inisiatif yang menarik perhatian dunia internasional adalah Belt and Road Initiative (BRI) pada tahun 2013 yang bertujuan menghubungkan ekonomi Eurasia dengan infrastruktur, perdagangan, dan investasi. BRI terdiri dari 2 komponen utama yaitu the Silk Road Economic Belt dan the 21st Century Maritime Silk Road. Silk Road Economic Belt sebagai jalur darat bertujuan menghubungkan provinsi tertinggal bagian barat Tiongkok dengan Eropa melalui Asia Tengah. Sedangkan the 21st Century Maritime Silk Road sebagai rute laut bertujuan menghubungkan provinsi pesisir Tiongkok yang kaya dengan kawasan Asia Tenggara hingga Afrika melalui pelabuhan dan jalur kereta api. ${ }^{1}$ Dengan menghubungkan Tiongkok dengan berbagai belahan dunia maka Xi Jinping memimpikan sebuah jalan sutera besi bagi Tiongkok beserta kepentingannya.
BRI merupakan proyek raksasa karena melintasi 3 benua yaitu Asia, Eropa dan Afrika dan $3 / 4$ sumber energi dengan target 4.4 miliar populasi di 67 negara sehingga mewakili $63 \%$ dari total populasi global. ${ }^{2}$ Pengeluaran Tiongkok untuk BRI diperkirakan akan mencapai $\$ 100$ miliar per tahun. ${ }^{3}$ Untuk membiayai proyek BRI yang membutuhkan modal yang sangat besar tersebut maka Tiongkok kemudian mendirikan New Development Bank (2013), Asian Infrastructure Investment Bank (2014), Silk Road Fund (2015), dan mekanisme pendanaan lainnya, baik bilateral maupun multilateral.

Berdasarkan fakta di atas, tulisan ini akan membahas mengenai faktor-faktor apa saja yang melatarbelakangi munculnya BRI. Dalam analisis, penulis menggunakan perspektif neorealisme yang terdiri dari konsep kepentingan nasional, balance of power, dan hegemonic stability.

\footnotetext{
${ }^{1}$ Peter Cai. (2017, Maret). Understanding China's Belt and Road Initiative, Lowy Institute For International Policy, hal. 2. Diakses melalui: https://www.lowyinstitute.org/sites/default/files/do cuments/Understanding\%20China $\%$ E2\%80\%99s\% 20Belt\%20and\%20Road\%20Initiative_WEB_1.pdf
} 
Gambar 1. Peta BRI Tiongkok

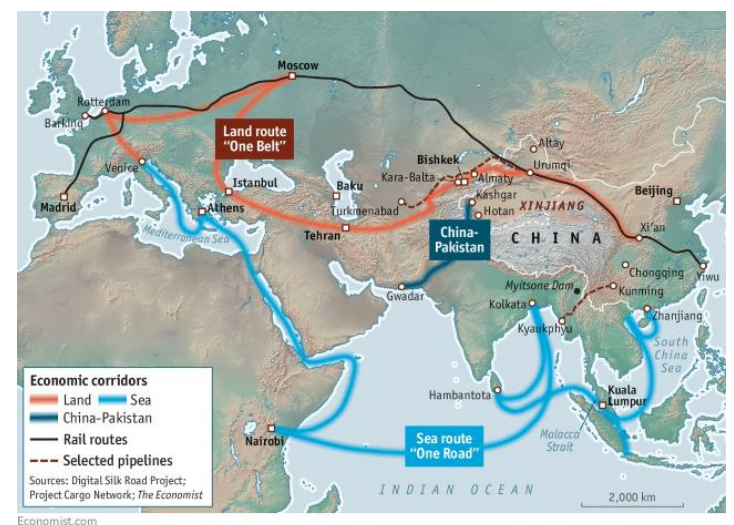

Sumber: Economist.com ${ }^{4}$

\section{Perspektif Neorealis}

Untuk menjawab permasalahan dalam tulisan ini penulis menggunakan perspektif neorealisme. Neorealisme sebagai salah satu teori hubungan internasional dimana Kenneth Waltz dan Mearsheimer merupakan dua pemikir neorealis terkemuka.

Kepentingan nasional merupakan salah satu konsep yang paling banyak dibicarakan. Dalam wacana politik internasional, konsep kepentingan nasional umumnya digunakan dalam menjelaskan perilaku negara atau kebijakan luar negeri yang diambil. Morgenthau mendefinisikan konsep kepentingan nasional dalam istilah "power" atau kekuasaan. Kepentingan nasional merupakan kondisi permanen yang memberi para pembuat kebijakan petunjuk rasional dalam menjalankan tugasnya. Kepentingan nasional juga biasanya didefinisikan dalam istilah strategi dan kapabilitas ekonomi karena politik internasional merupakan suatu struggle for power antarnegara. Morgenthau mengakui definisi power akan berubah tiap waktu.

\footnotetext{
4 The Economist. (2017, 4 Mei). China Faces Resistance to a Cherished Theme of its Fereign Policy. Diakses melalui: https://www.economist.com/news/china/21721678silk-routes-are-not-always-appealing-they-soundchina-faces-resistance-cherished-theme
}

Disatu sisi kekuasaan ekonomi akan menjadi krusial, namun disisi lain kekuasaan militer atau budaya menjadi kepentingan vital bagi negara. ${ }^{5}$

Waltz memiliki persepsi berbeda dengan kepentingan nasional Morgenthau. Menurutnya, kepentingan nasional bergerak seperti sinyal otomatis yang memerintahkan para pemimpin negara kapan dan kemana mereka harus bergerak. Letak perbedaannya adalah Morgenthau yakin bahwa para pemimpin negara wajib melaksanakan kebijakan luar negerinya dengan mengacu pada petunjuk yang digariskan oleh kepentingan nasional negara, dan mereka mungkin dipersalahkan ketika gagal melakukannya, sedangkan teori neorealis Waltz menghipotesiskan bahwa mereka akan selalu melakukannya secara otomatis. ${ }^{6}$

Neorealisme sendiri memiliki dua varian yaitu defensif dan ofensif. Salah satu tokoh neorealis defensif yaitu Kenneth Waltz melihat sistem internasional berjalan secara anarkis (suatu kondisi dimana tidak adanya otoritas tunggal yang dapat mengaturnya)

\footnotetext{
5 Scott Burchill. The National Interest in International Relations Theory (pp. 35-36). New York: Palgrave Macmillan.

${ }^{6}$ Robert Jackson \& George Sorensen, Pengantar Hubungan Internasional Teori dan Pendekatan, (pp. 140-141). Yogyakarta: Pustaka Pelajar. 2013.
} 
sehingga tiap negara akan menolong dirinya sendiri (self-help). Kondisi ini menurut Waltz akan memaksa tiap negara saling berusaha mengimbangi satu sama lain. Sejalan dengan pandangan Walz, Mearsheimer sebagai tokoh neorealis ofensif juga melihat bahwa struktur sistemlah yang menentukan bagaimana negara berperilaku dan bagaimana mereka memandang satu sama lain. ${ }^{7}$

Berbicara mengenai distribusi kekuasaan dalam politik internasional, balance of power dianggap sebagai salah satu upaya 'realistis' yang dapat dilakukan oleh para aktor internasional dalam menjaga kestabilan sistem internasional yang bersifat anarki. Dalam hubungan balance of power dengan neorealisme, Dougherty dan Pfalzgraff melihat empat prinsip dasar yaitu: Negara adalah aktor kunci dalam sistem internasional, kebijakan domestik dan luar negeri dipisahkan dengan kebijakan nasional, politik internasional adalah perebutan kekuasaan (struggle of power), dan negara mempunyai kapabilitas untuk meraih tujuan dan kepentingannya. ${ }^{8}$ Neorealis menekankan bahwa negara berjuang untuk meraih kekuasaan (power) dan mereka juga mengklaim bahwa terdapat sejumlah tetap power dalam sistem. Namun tidak mungkin jika semua aktor mendapatkan banyak kekuasaan dalam waktu yang bersamaan. Sehingga neorealis melihat hubungan tiap aktor dalam kerangka zero-sum game. ${ }^{9}$

Definisi Balance of power menurut Morgenthau mengacu pada suatu keadaan nyata dimana kekuasaan terbagi kurang lebih

\footnotetext{
7 Azwar Asrudin. Thomas Kuhn dan Teori Hubungan Internasional : Realisme Sebagai Paradigma. Indonesian Journal of International Studies (IJIS) 1, 2, pp. 113. Desember 2014.

${ }^{8}$ Michael Sheehan, The Balance of Power History and Theory (pp. 2-4). New York: Routledge. 1996. Diakses melalui: http://rinslab.com/wpcontent/uploads/2017/05/Michael_Sheehan_The_B alance_of_Power_History_an_BookFi.pdf

9 Fred Chernoff, Theory and Metatheory in International Relations (pp. 47). New York: Palgrave Macmillan. 2007.
}

sama diantara beberapa negara. Sedangkan Vattel mendefinisikannya sebagai sebuah ketetapan dimana tidak ada negara yang berada dalam posisi memiliki penguasaan mutlak dan mendominasi yang lain. Dalam daftar definisi yang dicatat oleh Dina Zinnes menunjukkan bahwa balance of power melibatkan distribusi kekuasaan diantara negara dalam sistem internasional dimana tidak ada negara tunggal dan tidak ada aliansi yang memiliki jumlah berlebih. ${ }^{10}$ Oleh karena itu suatu negara secara otomatis akan menyesuaikan diri jika pihak lainnya meningkatkan kekuatannya.

Waltz dan Mearsheimer memiliki pandangan yang berbeda mengenai tujuan negara. Menurut Waltz, tujuan negara-negara adalah hanya mengejar keamanan dan mengumpulkan kekuasaan untuk mempertahankan diri. ${ }^{11}$ Walaupun dalam hal ini Mearsheimer sependapat dengan Waltz bahwa anarki memaksa negara-negara untuk bersaing demi kekuasaan, namun Mearsheimer percaya bahwa tiap negara akan berupaya untuk menjadi kekuatan hegemon dan lebih agresif dari yang dibayangkan oleh Waltz. Tujuan negara menurutnya adalah mendominasi seluruh sistem dan menjadi pihak yang berkuasa di satu kawasan dunia (menjadi hegemon regional). Berbeda dengan Waltz dimana menurutnya padangan Mearsheimer kurang tepat karena dengan menjadi begitu berkuasa, negara lain pasti akan berupaya untuk mengimbangi dan melawannya. ${ }^{12}$

Teori neorealis Mearsheimer mengarahkan kita untuk mempercayai bahwa apabila Tiongkok muncul sebagai hegemon potensial di kawasan Asia, maka Amerika Serikat akan bereaksi untuk mencegah kekuatan Tiongkok di kawasan tersebut. Inilah

\footnotetext{
${ }^{10}$ Michael Sheehan, pp. 2-4.

11 Abubaka Ebihara, Pengantar Analisa Politik Luar Negeri: dari Realisme sampai Konstruktivisme (pp. 114). Bandung: Nuansa Cendekia. 2011.

12 Azwar Asrudin, pp. 114.
} 
yang ia sebut sebagai neorealisme ofensif dimana kekuatan besar akan selalu berusaha mendapatkan kekuatan melebihi pesaingnya dengan hegemoni sebagai cita-citanya. ${ }^{13}$ Hegemoni versi neorealisme memiliki corak yang lebih mengarah kepada dominasi daripada kepemimpinan moral dan intelektual.

Terdapat determinan umum mengenai sumber kekuatan hegemoni seperti unit currency, kekuatan militer, kepemiminan dalam penanganan krisis dan konflik regional, kepemilikan senjata nuklir, dan sebagainya. Brzezinski mengkalim bahwa troika hegemoni terdiri dari keuangan, kapasitas produksi, dan kekuatan militer. ${ }^{14}$ Sedangkan pencetus istilah "soft power", Joseph S. Nye membuat daftar mengenai sumber kekuatan hegemoni meliputi (1) Kepemimpinan teknologi, (2) Supremasi dalam militer dan ekonomi, (3) soft power, (4) Kontrol terhadap koneksi jalur komunikasi internasional. ${ }^{15}$ Terakhir, Susan Strange menekankan hegemoni didapat melalui 4 struktur yaitu struktur keamanan, produksi, keuangan, dan pengetahuan. ${ }^{16}$ Berdasarkan determinan hegemoni tersebut maka penulis menyimpulkan bahwa hegemoni tidak hanya bersumber dari hard power (kekuatan militer) namun juga soft power (ekonomi, budaya, pengetahuan dan sebagainya).

Berdasarkan penjelasan di atas maka neorealisme dapat menjelaskan mengenai faktor-faktor apa saja yang mendorong Tiongkok membuat kebijakan BRI, yaitu:

Pertama, Tiap negara bergerak secara otomatis atas dasar kepentingan nasional dalam hal ini Tiongkok berusaha untuk memenuhi kebutuhan energinya sehingga Tiongkok berusaha mencari alternatif pasokan

\footnotetext{
${ }^{13}$ Robert Jackson \& George Sorensen, pp. 147.

${ }^{14}$ Sait Yilmaz, State. Power, and Hegemony. International Journal of Business and Social Science 1, 3, pp. 195. Desember 2010. Diakses melalui:

http://ijbssnet.com/journals/Vol._1_No._3_Decemb er_2010/20.pdf

${ }^{15}$ Sait Yilmaz, pp. 196.

${ }^{16}$ Sait Yilmaz, pp. 195.
}

energi dan mengamankan jalur impor energi dari partner lamanya. Keamanan energi merupakan kepentingan vital bagi Tiongkok karena merupakan motor penggerak pembangunan industrinya. Kedua, Neorealisme berbicara mengenai distribusi kekuasaan dimana tiap negara selalu berusaha menyeimbangkan power dari negara lainnya. Dalam hal ini Tiongkok berusaha mencari kepemimpinan di Asia lewat pembiayaan proyek HSR yang bersaing ketat dengan Jepang. Ketiga, Neorealisme berbicara mengenai perilaku negara dalam sistem internasional yang menginginkan hegemoni di berbagai bidang. Dalam hal ini penulis melihat Tiongkok berusaha mencari hegemoni di bidang keamanan dengan berusaha membentuk tatanan keamanan baru dengan mengajak negara-negara untuk mengeluarkan AS dari urusan kemanan Asia. Sedangkan dibidang ekonomi, pembentukan AIIB menantang tatanan finansial regional (ADB) maupun global (World Bank dan IMF) serta aturan main yang telah lama digunakan dalam institusi-institusi tersebut.

\section{Kajian Literatur}

Dalam tulisan ini akan dibahas mengenai faktor apa saja yang mendorong Tiongkok membuat kebijakan BRI dari perspektif neorealisme. Beberapa penelitian sebelumnya telah dilakukan oleh peneliti dan lembaga lain, misalnya penelitian mengenai alasan Tiongkok mengeluarkan kebijakan BRI dilakukan oleh Passalacqua Claudio Christopher. ${ }^{17}$ Dalam menjawab rumusan masalah penelitian tersebut Passalacqua Claudio Christopher menggunakan dua perspektif HI yaitu realisme dan liberalisme. Dengan pandangan realisme ia memaparkan tiga asumsi dasar yaitu: pertama karena kepentingan Tiongkok dalam mengamankan sumber energinya lewat

\footnotetext{
${ }^{17}$ Lihat Passalacqua Claudio Christopher. Chinas's New Opening Up Policy: The One Belt One Road Initiative, LUISS. Diakses melalui: http://tesi.eprints.luiss.it/17970/1/625102_PASSAL ACQUA_CLAUDIO\%20CHR.pdf
} 
kerjasama dengan negara-negara Asia Selatan seperti Pakistan dan Sri Lanka namun kerjasama tersebut hanya untuk memenuhi kepentingan nasional Tiongkok daripada mendukung pembangunan di wilayah tersebut. Kedua, perluasan pengaruh di kawasan Asia Selatan dengan pembangunan infrastruktur sekaligus membatasi pengaruh India di kawasan tersebut dengan membangun hubungan Sino-Pakistan sehingga memungkinkan Pakistan berada pada posisi "under a Chinese security blanket". Ketiga, AIIB dan SRF yang dibangun Tiongkok menantang tatanan regional dan global dengan melihat pembangian hak suara dalam AIIB dan lembaga finansial lainnya. Sedangkan dengan perspektif liberalisme maka didapat tiga asumsi yaitu pertama, Tiongkok ingin membangun kembali ekonominya dengan memperkuat hubungan ekonomi antara provinsi bagian timur yang kaya dan bagian barat yang tertinggal beserta negara-negara tetangganya. Kedua, BRI sebagai alat untuk meningkatkan integrasi ekonomi dengan pembangunan inftrastruktur di kawasan. Ketiga, pembiayaan BRI lewat AIIB dan SRF hanya berusaha melengkapi sistem internasional dengan mendorong reformasi pada institusi tersebut. Sehingga kedua perspektif $\mathrm{HI}$ tersebut bertolak belakang dalam melihat alasan Tiongkok dibalik kebijakan BRI. Namun pada akhirnya penulis tesis ini memenangkan pandangan liberalisme dengan mengambil kesimpulan bahwa alasan Tiongkok mengeluarkan BRI karena Tiongkok ingin menciptakan koridor ekonomi baru berdasarkan win-win cooperation. Selain itu juga berkaitan dengan kepentingan Tiongkok untuk meningkatkan integrasi regional dan terakhir keinginan Tiongkok untuk meningkatkan/memperbaiki global governance. Perspektif liberalisme ini yang dijadikan oleh penulis tesis tersebut sebagai landasan dalam menjelaskan beberapa materi tulisan selanjutnya.

Adapun persamaan antara tulisan ini dengan literatur pertama yaitu dalam fokus analisis mengenai alasan Tiongkok mengeluarkan kebijakan BRI. Namun perbedaan mendasar terletak pada perspektif yang digunakan. Jika literatur pertama menghadirkan pandangan dari dua teori $\mathrm{HI}$ yaitu liberalisme versus realisme dimana liberalisme yang menjadi pondasi tulisan tersebut. Perspektif liberalisme juga terlihat dalam keberpihakan Passalacqua Claudio dalam memenangkan pandangan Tiongkok daripada AS yang terangkum dalam Chapter III dan IV. Sedangkan penulis hanya menggunakan satu teori yaitu teori neorealisme sebagai pondasi tulisan. Bagi penulis, walaupun dalam kerangka kerjasama, negara cenderung mengejar kepentingan pribadi (self-interest) dimana negara selalu termotivasi mencari kekuasaan yang lebih besar. Dalam hal ini kepentingan nasional berupa keamanan energi, power maupun hegemoni.

Selain itu, penelitian yang membahas mengenai bagaimana implementasi BRI Tiongkok dan implikasinya bagi Amerika Serikat juga dilakukan oleh Indriana Kartini. ${ }^{18}$ Dalam penelitiannya dibahas mengenai faktorfaktor internal dan eksternal yang mendorong pemerintah Tiongkok mengeluarkan kebijakan BRI dan implementasinya terhadap hegemoni AS di dunia. Indriana Kartini menjawab pertanyaan dalam tulisan tersebut dengan menggunakan konsep geopolitik dan geoekonomi, dimensi kebijakan luar negeri dan konsep hegemonic stability. Ia memaparkan menganai faktor domestik yang mendorong Tiongkok mengeluarkan kebijakan BRI yaitu untuk mengatasi gejolak politik dalam lingkup domestiknya terutama gejolak yang ada di Xinjiang dengan memberikan jaminan pembangunan ekonomi. Faktor domestik lainnya terkait keamanan energi dimana terjadi peningkatan kebutuhan minyak dalam negeri sehingga BRI memungkinkan Tiongkok mengamankan dan meningkatkan

\footnotetext{
${ }^{18}$ Indriana Kartini. Kebijakan Jalur Sutra Baru Cina dan Implikasinya bagi Amerika Serikat. Jurnal Kajian Wilayah 6, 2. 2015.
} 
jalur suplai impor energi dari negara Asia Tengah dan untuk mengurangi efek pemutusan suplai dari Timur Tengah, Afrika atau Rusia. Terakhir, keinginan Bieijing untuk menjamin pasar ekspor dan diversifikasi jaringan transportasinya. Sedangkan jika dilihat dari isu internasional yang paling dominan mempengaruhi yaitu kebijakan "Pivot to Asia" AS masa pemerintahan Obama untuk membendung kekuatan Tiongkok di Asia sehingga BRI merupakan kebijakan yang dikeluarkan Tiongkok untuk membendung kekuatan AS di Asia Pasifik. Ia melihat implikasi BRI terhadap AS dari dua sisi yaitu sebagai ancaman maka AS melobi beberapa negara untuk membatalkan kerjasama dengan Tiongkok. Sebaliknya jika melihat sebagai peluang maka akan memberikan tanggapan positif agar Washington dapat meraih keuntungan ekonomi dari kebijakan BRI Tiongkok.

Dalam tulisan di atas penulis melihat bahwa faktor domestik yang dipaparkan cukup menjelaskan motivasi Tiongkok mengeluarkan kebijakan BRI karena beberapa kebijakan Tiongkok umumnya dipengaruhi oleh keadaan dalam negeri negara tersebut. Salah satu faktor domestik yang memiliki kesamaan dengan jawaban penulis yaitu terkait kepentingan nasional Tiongkok dalam mengamankan jalur pasokan energinya di Asia Tengah dengan membangun kerjasama dengan beberapa negara di Asia Selatan. Jika dilihat dari faktor internasional, penulis merasa penjelasan yang dipaparkan yaitu kebijakan "“'Pivot to Asia" AS masih belum cukup menjadi alasan Tiongkok mengeluarkan kebijakan BRI. Penulis merasa perlu melihat dari sisi pembiayaan proyek kereta cepat di Asia sebagai wujud ambisi Tiongkok untuk melebarkan pengaruhnya di tiap kawasan di Asia sehingga nantinya Tiongkok berhasil mencapai posisi sebagai leader kawasan. Selain itu juga motif hegemoni perlu untuk dibahas karena tiap negara dalam sistem internasional selalu berusaha mencari kekuasaan yang labih tinggi yaitu hegemoni.

\section{Kepentingan Nasional : Keamanan Energi}

Asumsi pertama mengenai faktor yang mendorong Tiongkok mengeluarkan kebijakan BRI yaitu kepentingan nasional Tiongkok dalam mencari suplai energi alternatif yaitu dari Asia Tengah (Kazakhstan dan Turkmenistan) serta mencari jalur alternatif bagi impor energi Tiongkok dari partner lamanya (Timur Tengah, Afrika dan Rusia).

Tiongkok merupakan ekonomi terbesar kedua di dunia dengan GDP sebesar US\$ 11.19 triliun pada tahun $2016 .{ }^{19}$ Transformasi ekonomi Tiongkok sejak era Deng Xioping telah membawa posisi Tiongkok mampu mengungguli GDP Jepang bahkan beberapa analis memprediksikan Tiongkok mampu melampaui AS sebagai ekonomi terbesar dunia. Semakin meningkatnya perekonomian Tiongkok disisi lain meningkatkan pula kebutuhan energi untuk menggerakkan sektor industrinya. Namun kebijakan pembangunan sektor energi belum mampu mengimbangi pesatnya pertumbuhan ekonomi tersebut. Untuk produksi minyak domestik Tiongkok hanya mampu menghasilkan $4.5 \%$, berbanding terbalik dengan konsumsinya yang menduduki peringkat kedua setelah Amerika Serikat. Bahkan permintaan minyak Tiongkok pada tahun 2010 mencapai 340 juta ton sementara produksi domestik hanyak dapat menyediakan 195 juta ton, sehingga defisit tersebut dapat dipenuhi dengan mengimpor dari negara lain. ${ }^{20}$ Padahal jika melihat pada pertengahan 1960-an, Tiongkok berhasil mencapai kemandirian minyak dan menjadi pengekspor minyak sebesar 36 juta toe pada tahun 1985. Namun ekspor Tiongkok

\footnotetext{
${ }^{19}$ World Bank, GDP Ranking, Diakses melalui: https://data.worldbank.org/data-catalog/GDPranking-table

20 Primadiana Yunita. Pemilihan Kazakhstan sebagai Mitra Kerjasama China dalam Sektor Energi Minyak tahun 2003-2010. Jurnal Ilmiah Transformasi Global 2, 2, pp. 102-103.
} 
mengalami penurunan dan Tiongkok mulai mengimpor sejak tahun $1993 .{ }^{21}$

Impor energi Tiongkok berasal dari Timur Tengah dan Afrika Sub Sahara. Namun karena adanya instabilitas politik di kedua kawasan sehingga memberikan kemungkinan berkurangnya suplai energi, serta permasalahan jalur maritim yang sering menjadi target pembajakan, membuat Tiongkok memikirkan cara untuk mengurangi ketergantungan impor energi dari negaranegara Timur Tengah dan Afrika Sub Sahara. Oleh karena itu Tiongkok meningkatkan impor energinya dari Rusia tiga kali lipat pada awal tahun 2000-an. Namun kondisi ini memberikan kekhawatiran baru bagi Tiongkok atas ketergantungan energinya dari Rusia sehingga Tiongkok kemudian mulai mencari sumber energi alternatif lainnya. Dua negara Asia Tengah yang kaya sumber energi yaitu Kazakhstan dan Turkmenistan menjadi partner potensial dalam menyediakan kebutuhan energi Tiongkok. Oleh karena itu, berbagai proyek BRI akan memberikan kesempatan bagi Tiongkok untuk mencari sumber energi alternatif serta untuk mengurangi efek potensial apabila terjadi pemutusan suplai dari pertner lamanya yang ada di Timur Tengah, Afrika, maupun Rusia. ${ }^{22}$

Selain mencari sumber energi alternatif, Tiongkok membuat kebijakan BRI untuk mempertahankan suplai energi dari parter lamanya yaitu Timur Tengah. Untuk mencapai tujuan ini maka Tiongkok menjalin hubungan yang lebih erat dengan beberapa negara termasuk Pakistan. Kerjasama erat dengan Pakistan ini diperlihatkan lewat proyek

\footnotetext{
${ }^{21}$ Zhidong Li, dkk. Energy Demand and Supply Outlook in China for 2030 and a Noetheast Asian Energy Community-The Automobile Strategy and Nuclear Power Strategy of China- (pp. 2). Diakses melalui: http://eneken.ieej.or.jp/en/data/pdf/300.pdf ${ }^{22}$ Camille Brugier. (2014, Mei). China's way: the New Silk Road, European Union Institute for Security Studies, pp. 3-4. Diakses melaui: https://www.iss.europa.eu/sites/default/files/EUISS Files/Brief_14_New_Silk_Road.pdf
}

infrastruktur seperti jalan raya, jalur kereta api, dan pipa gas, serta keputusan Pakistan memberikan kontrol dan manajemen operasional pelabuhan Gwadar di Lautan Arabia kepada perusahaan Tiongkok, menawarkan akses ke Teluk Persia dan seluruh kawasan Timur Tengah. Gwadar merupakan bagian dari Koridor Ekonomi TiongkokPakistan, dimana Tiongkok telah menandatangani perjanjian investasi pada April 2015 sebesar US\$48 milyar. Sebagai konsekuensinya, Tiongkok dengan cepat berhasil menggantikan AS sebagai mitra potensial Pakistan. ${ }^{23}$

Bagi Tiongkok, Pakistan merupakan sekutu strategis untuk melawan persekutuan India-AS maupun India-Jepang. Hubungan antara Tiongkok dan Timur Tengah melalui Pakistan akan memberikan cara yang lebih aman dan cepat untuk menyalurkan sumber daya seperti minyak dan gas dari Timur Tengah ke Tiongkok dan barang dagangan dari Tiongkok ke Timur Tengah dan Eropa. Jaringan pipa melalui Pakistan akan melayani tujuan serupa dengan yang berjalan melalui Myanmar, sehingga memungkinkan Tiongkok memiliki jalur baru bagi impor energi dari Timur Tengah tanpa melewati Selat Malaka dan Laut China Selatan. Jaringan pipa dan jalur transportasi darat melalui Pakistan ini akan mempersingkat jarak dan waktu tempuh apabila dibandingkan dengan rute lamanya melewati jalur laut di Selat Malaka ${ }^{24}$ Hal ini dikarenakan Selat Malaka memiliki beberapa kelemahan yaitu permasalahan cuaca buruk dan gelombang tinggi yang seringkali menyebabkan pelayaran tertunda. Akibatnya

\footnotetext{
${ }^{23}$ Alain Gudetti. The Silk Road, Sand Castles and the US-China Rivalry. Geneva Centre for Security Policy (GCSP), pp. 6. Juli 2015. Diakses melalui: http://www.gcsp.ch/News-

Knowledge/Publications/The-Silk-Road-SandCastles-and-the-US-China-Rivalry

24 Gerald Chan. China's High-Speed Rail Diplomacy: Global Impacts and East Asian Responses. East Asia Institute, pp. 17. Februari $2016 . \quad$ Diakses melalui: https://www.eai.or.kr/data/bbs/eng_report/2016021 517332269.pdf
} 
minyak yang diimpor melalui Timur Tengah dan Afrika tidak dapat bertahan lama. Selain itu juga terkait persoalan meningkatnya ancaman kejahatan maritim berupa pembajakan kapal, perampokan, penculikan awak kapal, dan berbagai persoalan maritim lainnya. ${ }^{25}$ Padahal hampir $85 \%$ impor Tiongkok dikirimkan melalui jalur ini, termasuk $80 \%$ impor energi. ${ }^{26}$ Selain Pakistan, Iran juga menawarkan saluran untuk memfasilitasi jangkauan Tiongkok ke Timur Tengah dan Eropa melalui koneksi darat dan laut. Xi Jinping adalah pemimpin dunia pertama yang mengunjungi Teheran pada Januari 2016, setelah pencabutan sanksi internasional terhadap Iran untuk memperkuat hubungan ekonomi dan politik antara kedua negara. $^{27}$

Berdasarkan penjelasan tersebut terlihat bahwa salah satu faktor yang mendorong Tiongkok membuat kebijakan BRI yaitu kepentingan nasional dalam menjamin keamanan energinya dimana pemenuhan suplai energi merupakan kepentingan krusial karena menyangkut sektor industri yang menjadi motor penggerak pembangunan negara tersebut.

\section{Ambisi Tiongkok Mengambil Alih Peran Kepemimpinan di Kawasan Asia}

Asumsi kedua penulis terkait dengan faktor yang mendorong Tiongkok membuat kebijakan BRI tidak lepas dari ambisi Tiongkok untuk mengambil alih peran sebagai pemimpin di kawasan Asia. Ambisi ini dapat dilihat dari usaha Tiongkok untuk menyebarluaskan pengaruhnya di Asia dalam pembiayaan proyek infrastruktur terutama proyek kereta cepat yang bersaing ketat dengan Jepang. Jika kita lihat kawasan Asia

\footnotetext{
${ }^{25}$ Primadiana Yunita, pp. 109-110.

${ }^{26}$ Felipe Umana. Transnational Security Threats in the Straits of Malacca (pp. 14). Washington, D.C: The Fund for Peace. 2012. Diakses melalui: http://library.fundforpeace.org/library/ttcvr1213threatconvergence-malaccastraits-08e.pdf 27 Gerald Chan.
}

memang tidak bisa lepas dari rivalitas the emerging actors yakni Tiongkok dan Jepang.

Ketika supremasi AS di kawasan semakin berkurang, Jepang dan Tiongkok berebut pengaruh untuk menempati posisi sebagai leader dalam waktu dekat. Beberapa dekade yang lalu Jepang berhasil memimpin kawasan Asia. Namun posisi ini ditantang dengan hadirnya Tiongkok sebagai kekuatan ekonomi yang diperkirakan mampu menggeser posisi Jepang sebagai leader dimasa depan.

Proyek High-Speed Railway (HSR) merupakan salah satu jenis proyek infrastruktur yang dipromosikan oleh BRI. Proyek ini menghubungkan negara-negara BRI dan untuk mempromosikan ekonomi serta perpindahan "people-to-people". HSR juga memiliki value-added yang sangat sejalan dengan upaya jangka panjang Beijing untuk mengekspor teknologi yang lebih canggih dan menyeimbangkan kembali ekonominya. Komitmen Tiongkok untuk berinvestasi di proyek infrastruktur melalui BRI merupakan peluang baik bagi perusahaan kereta api Tiongkok untuk memperluas jaringan pasar ke luar negeri. Selain itu HSR juga merupakan simbol kemajuan teknologi Tiongkok dimana Tiongkok berhasil membangun jaringan HSR terbesar di dunia dan mengembangkan perusahaan kereta api yang kompetitif secara global. ${ }^{28}$

Untuk perencanaan HSR di Tiongkok baru dimulai pada tahun 1990 saat dilaksanakannya Kongres Rakyat Nasional. Pada tahun 2002, Menteri Perkeretaapian Zhijiu Liu mengusulkan strategi Great Leap Forward yang mendorong ekspansi jaringan perkeretaapian dan sejumlah upgrade teknologi. ${ }^{29}$ Setelah satu dekade gagal

28 Michelle Ker. China's High-Speed Rail Diplomacy. U.S-China Economic and Security Review Commission, pp. 4. 21 Februari 2017. Diakses melalui: https://www.uscc.gov/sites/default/files/Research/C hina\%27s\%20High\%20Speed\%20Rail\%20Diplom acy.pdf

${ }^{29}$ Taufik Hidayat. MajalahKA.com. (2015, 12 Juli). Revolusi High Speed Rail (Bagian 6). Diakses 
mengembangkan teknologi HSR sendiri, Liu memutuskan menggunakan strategi technology transfer for market access dimana Tiongkok mengimpor dan merekayasa balik teknologi HSR dari perusahaan asing untuk mencapai sistem HSR yang diproduksi sendiri. ${ }^{30}$ Dua produsen utama kereta api Tiongkok, China Southern Railway Corporation (CSR) dan China Northern Railway Corporation (CNR), menandatangani kontrak transfer teknologi dengan Alstom (Prancis), Siemens (Jerman), Bombardier (Kanada), dan Kawasaki Heavy Industries (Jepang). ${ }^{31}$ Berdasarkan teknologi asing dan pengalamannya di industri kereta api di masa lalu, Tiongkok mulai mengembangkan teknologinya sendiri tahun 2007. Pada tanggal 1 Agustus 2008, HSR pertama Tiongkok mulai berjalan antara Beijing dan Tianjin. Pada tahun 2009 Tiongkok memutuskan untuk menyebarkan investasi HSR secara global dimana hal ini memperlihatkan transisi industri dari "made in China" sebagai barang manufaktur menjadi "created in China" sebagai inovasi teknologi dan promotor. ${ }^{32}$ Pada Oktober 2010, Tiongkok memperkenalkan China Railway High-Speed (CRH) 380A yang menghubungkan ShanghaiNanjing dengan kecepatan maksimal 380 $\mathrm{km} / \mathrm{jam}$. Tiongkok kembali memperkenalkan Shanghai Maglev pada 1 Januari 2004 sebagai kereta tercepat di dunia dengan kecepatan maksimum $430 \mathrm{~km} / \mathrm{jam}$ yang beroperasi di

melalui: http://majalahka.com/revolusi-high-speedrail/

${ }^{30}$ Damien Ma. The Atlantic. (2011, 30 Maret). China's Long, Bumpy Road to High-Speed Rail. Diakses melalui: https://www.theatlantic.com/international/archive/2 011/03/chinas-long-bumpy-road-to-high-speedrail/73192/

31 Yatang Lin, Yu Qin, dan Zhuan Xie, International Technology Transfer and Domestic Innovation: Evidence from the High-Speed Rail Sector in China, The London School of Political Science (LSE), pp. 4. Desember 2015. Diakses melalui:

http://cep.lse.ac.uk/pubs/download/dp1393.pdf

32 Gerald Chan, pp. 1-2. jalur levutasi magnetis di kota Shanghai. ${ }^{33}$ Sebagai latecomer, Tiongkok mampu mengejar ketertinggalannya bahkan dari Jepang yang merupakan negara pertama yang mengembangkan HSR dengan strategi tecnological leafrogging hingga akhirnya membawa Tiongkok menjadi pengekspor HSR di Asia bahkan berbagai belahan dunia lainnya.

Diplomasi HSR Tiongkok jika dianalisis lebih mendalam dimotivasi oleh kombinasi kebijakan luar negeri dan tujuan ekonomi domestik. Bagi pemerintah Tiongkok, proyek HSR melalui BRI merupakan bagian dari rencana Beijing untuk menjadi pemimpin global dalam manufaktur bernilai tambah tinggi, sekaligus membantu menyerap kelebihan kapasitas industri di negaranya. Motivasi lainnya yaitu dapat menjadi sarana untuk meningkatkan pengaruh politik yang lebih luas dengan memperdalam hubungan bilateral dengan negara mitranya. ${ }^{34}$ Sehingga nantinya posisi sebagai leader kawasan dapat dipegang oleh Tiongkok.

Untuk mengimbangi pengaruh Tiongkok dalam proyek infrastruktur di Asia, Perdana Menteri Jepang, Shinzo Abe kemudian mengumumkan bantuan senilai \$110 miliar ( 13 triliun) untuk pembangunan infrastruktur "berkualitas tinggi" di Asia. ${ }^{35}$ Dana tersebut disalurkan melalui JICA dan ADB. Inisiatif ini kemudian disebut Partnership for Quality Infrastructure (PQI) yang bertujuan untuk memperluas kehadiran Jepang di negara berkembang. Dengan menekankan pada kualitas, Jepang berusaha mengambil proyek

33 Ervan Hardoko, kompas.com. (2016, 6 September). Inilah 10 Kereta Api Tercepat di Dunia. Diakses melalui: http://internasional.kompas.com/read/2016/09/06/1 7400981/inilah.10.kereta.api.tercepat.di.dunia?page $=$ all

${ }^{34}$ Michelle Ker, pp. 3.

${ }^{35}$ Masaaki Kameda, Abe Announces $\$ 110$ Billion in Ais for 'High-Quality' Infrastructure in Asia, The Japan Times, 22 Mei 2015. Diakses melalui: https://www.japantimes.co.jp/news/2015/05/22/bus iness/abe-announces-110-billion-in-aid-for-highquality-infrastructure-in-asia/\#.WfneKjufLIU 
Tiongkok yang secara teknologi lebih rendah dari Jepang. Ketika mengumumkan rencana PQI ini, Abe mengkritik AIIB karena kurangnya standar transparansi dan tata kelola yang bertepatan juga dengan usaha Tiongkok mempromosikan BRI. Abe juga telah merencanakan untuk mereformasi ADB sebagai respon terhadap AIIB. ${ }^{36}$

Rivalitas yang terjalin antara Tiongkok dan Jepang dalam proyek HSR di Asia penulis lihat sebagai suatu babak baru perebutan pengaruh untuk mendapat gelar sebagai leader kawasan. HSR Tiongkok dan Jepang memiliki keunggulan masing-masing dalam memenangkan proyek di luar negeri. Jika Tiongkok lebih menekankan pada pendekatan low cost maka Jepang lebih kepada pendekatan high quality. Namun Tiongkok selangkah didepan Jepang karena dengan mengelurkan kebijakan BRI maka HSR Tiongkok semakin gencar dipromosikan sepanjang proyek BRI.

Untuk mengetahui sejauh mana pengaruh BRI Tiongkok di kawasan Asia terutama dalam proyek HSR maka penulis menilainya dari bagaimana respon beberapa negara terhadap inisiatif ini. Adapun respon dari kawasan Asia Timur dimana penulis mengambil sample Korea Selatan. Korsel nampaknya lebih mendukung diplomasi HSR Tiongkok daripada Jepang. Seiring dengan penguatan hubungan bilateral kedua negara dimana Tiongkok merupakan mitra dagang terbesar Korsel dan akhirnya pada tahun 2015 ditandatanganinya Korsel-Tiongkok FTA, Korsel juga merespon positif proyek infrastruktur BRI lainnya. ${ }^{37}$ BRI Tiongkok dianggap sejalan dengan "Eurasia Initiative

\footnotetext{
${ }^{36}$ Jyotishman Bhagawati, Japan's Grand Strategy to Counter China: An Analysis of the "Partnership for Quality Infrastructure (pp. 2). New Delhi: Institute of Chinese Strudies (ICS). Agustus 2016. Diakses melalui: http://www.icsin.org/uploads/2016/08/22/6b23d4cc 33b9cfe11c7a41ca13c81600.pdf

37 Alice Ekman, China's Rise: the View From South Korea, European Union Institute for Security Studies (EUISS), Mei 2016, pp. 1. Diakses melalui: https://www.iss.europa.eu/sites/default/files/EUISS Files/Alert_19_China_ROK.pdf
}

(EAI)" yang diumumkan Park Geun-Hye pada tanggal 18 Oktober 2013. Tujuan EAI bukan hanya dilihat sebagai tujuan secara geografis menghubungkan Eropa Barat dengan pilar paling timur Asia, ujung selatan dari Semanjung Korea, namun juga tujuan politik untuk mengubah geopolitik dan keamanan Asia Timur. ${ }^{38}$

Negara-negara di Asia Tenggara juga cenderung memberikan respon positif terhadap BRI Tiongkok. Filipina berencana untuk meminjam \$ 3.4 milyar dari Tiongkok. Terdapat tiga proyek infrastruktur yang telah disepakati antara Tiongkok dan Filipina, terutama untuk proyek irigasi, penyediaan air bersih dan kereta api. Begitupula dengan Vietnam yang mencari investasi infrastruktur yang berasal dari AIIB, dengan total investasi sekitar \$50 miliar. Hal ini dikarenakan Vietnam menghadapi beberapa permasalahan seperti kemacetan lalu lintas, penanganan limbah dan masalah infrastruktur transportasi perkotaan. Thailand juga bersedia untuk mengembangkan proyek infrastruktur, terutama kegiatan perkeretaapian. ${ }^{39}$ Dalam hal ini, Pemerintah Thailand nampaknya berusaha untuk dapat mengakomodasi untuk bekerjasama dengan Tiongkok dan juga Jepang dengan membangun dua jalur kereta api yang terpisah. Indonesia juga memperlihatkan ketertarikan dengan BRI Tiongkok. Bagian maritim yang disebut 21st Century Maritime Silk Road sejalan dengan kebijakan Indonesia sebagai poros maritim dunia yang dipromosikan oleh Presiden Joko Widodo. Perry Warjiyo, wakil gubernur Bank Indonesia, menyatakan bahwa dalam lima tahun ke depan, Indonesia akan membangun 15 bandara baru, memperluas 40 bandara yang ada dan 15 pelabuhan laut, dan membangun infrastruktur jalan dan kereta api. Dalam hal

\footnotetext{
${ }^{38}$ Balbina Hwang, What South Korea Thinks of China's 'Belt and Road', The Diplomat, 14 Januari $2017 . \quad$ Deiakses melalui: https://thediplomat.com/2017/01/what-south-koreathinks-of-chinas-belt-and-road/ ${ }^{39}$ Penelope Marbler \& Lea Shan, pp. 3.
} 
ini Indonesia membutuhkan $\$ 230$ miliar per tahun untuk tujuan tersebut. Indonesia kemudian menjadi negara pertama yang mengajukan permohonan dana dari AIIB tahun 2016 saat bank tersebut mulai beroperasi. ${ }^{40}$ Sinyal positif lainnya dari Indonesia yaitu dimenangkannya proyek kereta cepat JakartaBandung kepada Tiongkok daripada Jepang.

Berbeda dengan kedua kawasan di atas, respon Asia Selatan cenderung seimbang jika melihat tanggapan India, Bangladesh dan Pakistan. Setelah kalah dari Tiongkok dalam proyek kereta cepat di Indonesia, Jepang menawarkan persyaratan pinjaman yang menarik dan teknologi Shinkansen untuk proyek kereta cepat Mumbai-Ahmedabad selama kunjungan Shinzo Abe ke India pada bulan Desember 2015. Namun, dalam hal ini India menghadapi dilema karena India merupakan pemangku kepentingan terbesar kedua di AIIB serta anggota Bank Pembangunan BRICS dimana keduanya berada di bawah inisiatif Tiongok. Pada akhirnya, India menunjukkan sikap yang lebih terbuka kepada PQI Jepang dibanding BRI Tiongkok. ${ }^{41}$ Alasan utama India cenderung memilih Jepang daripada Tiongkok dikarenakan inisatif BRI Tiongkok dilihat oleh India mengintervensi pengaruh India di Asia Selatan. India dalam hal ini merupakan salah satu emerging power di Asia selain Jepang yang dapat menandingi Tiongkok. Selain itu kemitraan India-Jepang menjadikan India sebagai penerima terbesar program ODA Jepang. Apalagi India dan Jepang juga terlibat dalam pertahanan strategis dan kemitraan ekonomi. Bangladesh juga baru-baru ini telah beralih ke Jepang dalam pembangunan infrastrukturnya. Pada bulan September 2015 JICA menawarkan kepada Bangladesh pinjaman senilai 3,7 miliar dolar AS dengan persyaratan mudah (tingkat bunga 0,1 persen selama tiga puluh tahun dengan masa tenggang sepuluh tahun) untuk membiayai

\footnotetext{
${ }^{40}$ Gerald Chan, pp. 15.

${ }^{41}$ Jyotishman Bhagawati, pp. 4-5.
}

pembangunan empat pembangkit listrik tenaga batubara yang masing-masing $600 \mathrm{MW}$ dan kompleks pelabuhan di Matarbari, di bagian tenggara. ${ }^{42}$ Sedangkan Pakistan cenderung memihak kepada Tiongkok daripada Jepang seperti dalam penjelasan pada asumsi pertama. Sehingga memicu keselarasan strategis terhadap keseimbangan antara dua kelompok negara: Jepang-India-Bangladesh berhadapan dengan Tiongkok-Pakistan. Untuk di Asia Tengah terdapat beberapa proyek yang diinisiasi oleh Tiongkok diantaranya proyek pipa minyak Tiongkok-Kazakhstan, pipa gas Turkmenistan-Tiongkok, dan kereta api Tiongkok-Kyrgyzstan. ${ }^{43}$

Fakta bahwa beberapa negara Asia cenderung menyambut baik proyek BRI Tiongkok menjadi indikasi bahwa pengaruh Tiongkok yang semakin meningkat di tiap kawasan Asia.

\section{Upaya Hegemoni Tiongkok melalui BRI}

Neorealisme juga berbicara mengenai perilaku negara dalam sistem internasional yang menginginkan hegemoni di berbagai bidang. Dalam hal ini penulis berusaha memperlihatkan upaya hegemoni Tiongkok melalui kebijakan BRI.

\section{Bidang Keamanan}

Melalui kebijakan BRI, Tiongkok berusaha membangun tatanan politik dan keamanan baru di Asia bahkan kawasan lainnya. Dalam bidang keamanan terutama kebijakan maritimnya, Tiongkok memperlihatkan dua sisi yang berbeda yaitu kerjasama dan kedaulatan. Disatu sisi Tiongkok mengambil sikap tegas atas beberapa permasalahan maritim yang dirasa melanggar kedaulatan maritimnya, namun disisi lain Tiongkok aktif membangun

\footnotetext{
42 Gerald Chan.

${ }^{43}$ Penelope Marbler \& Lea Shan
} 
kerjasama dan diplomasi terhadap negaranegara tetangganya.

Salah satu contohnya dalam merespon sengketa Laut Cina Selatan (LCS). Atas nama kedaulatan maritim, Tiongkok mengambil sikap tegas atas klaim yurisdiksinya di LCS dengan membangun pulau-pulau buatan untuk pangkalan militernya dan melakukan diplomasi koersi terhadap negara-negara penuntut lainnya. Ketegangan di wilayah sengketa memunculkan sistem balance of power akibat kebijakan Filipina dan Vietnam yang menarik kekuatan maritim lainnya seperti AS dan Jepang dalam sengketa tersebut. ${ }^{44}$

Karena semakin meningkatnya kehadiran AS di LCS maka Presiden Xi Jinping mengusulkan New Asian Security Concept yang berdasarkan pada community of common destiny sebagai wujud usaha Tiongkok dalam membatasi hegemoni AS di Asia dalam bidang keamanan. Presiden Xi beberapa kali menekankan bahwa Tiongkok dan negara tetangganya merupakan sebuah community of common destiny yang melampui kepentingan individual mereka dengan mengkonseptualisasi 4 kebijakan luar negeri baru Tiongkok yaitu : friendship ( 親), faithfulness (誠), benefits (惠), dan tolerance ( 容). ${ }^{45}$ Hal ini tercermin dalam pidatonya di depan Parlemen Indonesia pada tanggal 2 Oktober 2013 dimana Presiden Xi Jinping mengusulkan pembentukan China-ASEAN community with a common destiny dan 21st Century Maritime Silk Road. ${ }^{46}$ Begitu pula ketika dalam pidatonya di hadapan 26 negara anggota Conference on Interaction and

${ }^{44}$ Renato Cruz De Castro, The Challenge of Conflict Resolution in the South China Sea Dispute: Examining the Prospect of a Stable Peace in East Asia, International Journal of China Studies, Vol. 7 No. 1, April 2016, pp. 23-24.

${ }^{45}$ Changhoon CHA, China's Westward March: Strategic Views of One Belt One Road, The Korean Journal of International Studies, Vol. 15 No. 3, Desember 2017, pp. 491-492.

${ }^{46}$ Renato Cruz De Castro, pp. 42.
Confidence Building Measures in Asia (CICA). Usulan $\mathrm{Xi}$ Jinping ini tentu menantang peran global AS karena $\mathrm{Xi}$ meminta anggota CICA menolak aliansi militer sebagai basis keamanan regional dan menekankan bahwa hal tersebut merupakan urusan Asia untuk menangani masalahnya sendiri. Lingkup keamanan yang diusulkan Tiongkok mencakup keamanan tradisional dan non-tradisional serta pembangunan ekonomi tetapi tidak akan mencakup aliansi militer. Gagasan Xi Jinping bahwa interdependensi ekonomi akan membawa perdamaian. ${ }^{47}$

Perubahan narasi permusuhan Tiongkok dalam sengketa LCS dengan mengaitkan citra "partnership and friendship" merupakan suatu upaya Tiongkok mengubah corak upaya hegemoninya agar tidak dianggap sebagai suatu ancaman bagi negara-negara Asia. Sehingga nantinya negara-negara Asia akan lebih terbuka dalam merespon berbagai proyek BRI lainnya. BRI dalam hal ini memainkan peran penting dalam pengaturan kembali tatanan keamanan di kawasan Asia. Hal ini didukung dengan keluarnya AS dari Trans Pacific Partnership (TPP) menyebabkan negara-negara di Asia Pasifik memikirkan kembali jalinan aliansi yang telah mereka bangun dengan AS. Pergeseran yang paling mencolok dapat dilihat dalam kebijakan Presiden Filipina, Rodrigo Duterte yang secara terbuka menandatangani beberapa perjanjian ekonomi bilateral dengan Tiongkok bahkan Tiongkok memberikan bantuan senjata untuk Filipina dalam menangani terorisme di Mindanao padahal kedua negara memiliki permasalahan maritim dalam sengketa LCS. ${ }^{48}$

47 David Arase, China's Two Silk Roads: Implications for Southeast Assia, ISEA Perspective, Singapura, 22 Januari 2015, pp. 10.

${ }^{48}$ M. Najeri Al Syahrin, China Versus Amerika Serikat : Interpensi Rivalitas Keamanan Negara Adidaya Di Kawasan Asia Pasifik, Global \& Strategis, Th. 12 No. 1, Januari-Juni 2018, pp. 157. 


\section{Bidang Ekonomi: Pembentukan AIIB}

Dalam bidang ekonomi, kebijakan BRI Tiongkok diperkuat dengan pembentukan AIIB pada tahun 2015. AIIB mulai beroperasi pada 16 Januari 2016 dimana pada saat ini terdiri dari 84 anggota yang terbagi kedalam 40 anggota regional, 21 anggota non-regional, dan 23 anggota menyusul. Terdapat 24 proyek yang telah disepakati dalam berbagai sektor dengan pinjaman sebesar $\$ 4.22$ milyar. ${ }^{49}$ Secara tata kelola, AIIB terbuka untuk semua negara, namun seperti Asian Development Bank (ADB), AIIB juga membedakan antara anggota regional dan non-regional untuk membatasi ukuran pemungutan suara nonregional sehingga mempertahankan suara Asia. Oleh karena itu AIIB menetapkan 75\% suara anggota regional dimana saat ini anggota regional menguasai $77 \%$ saham dalam AIIB. ${ }^{50}$

AIIB memiliki tiga kategori hak suara yaitu basic votes, share votes dan Founding Member votes. Basic votes adalah jumlah suara yang dihasilkan melalui pembagian merata diantara anggota dari $12 \%$ jumlah keseluruhan basic votes, share votes dan Founding Member votes. Sedangkan share votes adalah sama dengan jumlah saham yang dimiliki anggota. Founding Member votes atau setiap anggota pendiri selanjutnya mendapat 600 suara. $^{51}$

49 Asian Infrastructure Investment Bank, Homepage. Diakses melalui: https://www.aiib.org/en/index.html

50 Liam Gennari, Power Transition and International Institution: China's Creation of the Asian Infrastructure Investment Bank, University of Pennsylvania, 21 April 2017, pp. 100-101. Diakses melalui: http://repository.upenn.edu/cgi/viewcontent.cgi?arti cle $=1025 \&$ context $=$ ppe_honors

${ }_{51}$ Asian Infrastruktire Investment Bank (AIIB), Article of Agreement, pp. 6. Diakses melalui: https://www.aiib.org/en/about-aiib/basicdocuments/_download/articles-ofagreement/basic_document_englishbank_articles_of_agreement.pdf 
Diagram 1. Voting Shares by Country-The ADB \& The AIIB
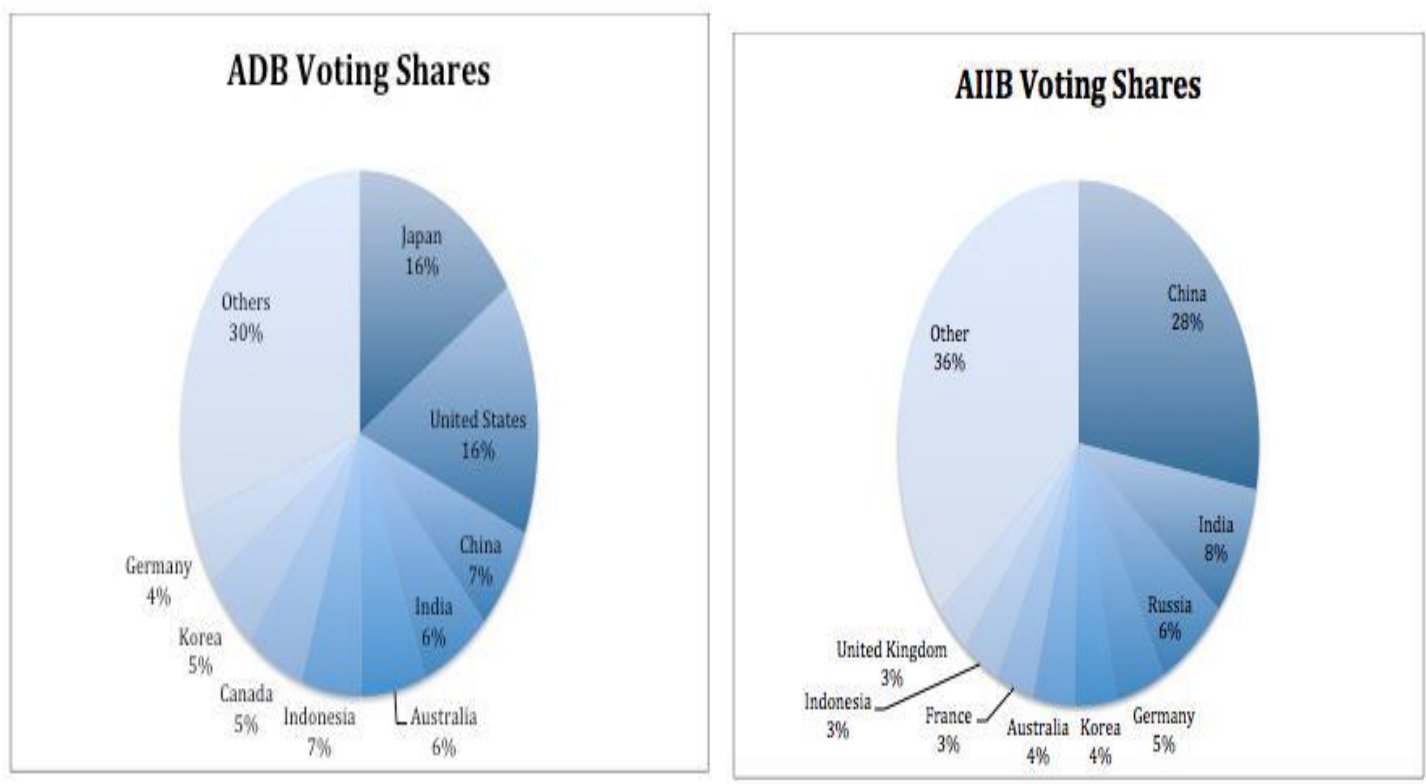

Sumber: Liam Gennari ${ }^{52}$

Berdasarkan diagram voting share di atas terlihat perpindahan saham di AIIB dari Global North (negara maju) ke Selatan (negara berkembang) dan Timur ke Barat. Jika di ADB Tiongkok hanya memiliki $7 \%$ suara berdasarkan saham yang dimiliki maka di AIIB Tiongkok memiliki $27,84 \%$ suara. Perbedaan ini didorong dengan penolakan AS dan Jepang untuk bergabung dengan AIIB membuat porsi untuk Tiongkok dan India jauh lebih besar. Fakta bahwa Tiongkok memiliki $27,84 \%$ saham artinya Tiongkok mengendalikan lebih dari $25 \%$ sehingga memberikannya hak veto secara de facto atas beberapa keputusan penting yang membutuhkan mayoritas super. Hal ini sesuai dengan pasal 28 (ii) yang menyatakan bahwa:

"A Super Majority vote of the Board of Governors shall require an affirmative vote of two-thirds of the total number of

${ }^{52}$ Liam Gennari, pp. 102.
Governors, representing not less than three-fourths of the total voting power of the members." 53

Hak suara yang dimiliki Tiongkok ini telah memicu spekulasi bahwa AIIB benar-benar dijadikan alat oleh PKC yang diarahkan untuk memenuhi kepentingannya sendiri. Selain itu juga terdapat ketakutan akan meningkatnya kewenangan manajemen AIIB yang diisi oleh mantan pejabat World Bank dan ADB. Hal ini terkait fakta bahwa Presiden Jin Liquin yang diangkat sebagai direktur eksekutif dari World Bank Group pada tahun 1988 dan menjabat sebagai wakil presiden ADB dari tahun 2003 hingga 2008 dimana Jin juga membawa tim dari ADB dan beberapa pegawai World Bank. ${ }^{54}$ Fakta tersebut merupakan sinyal mengenai prioritas dan visi Tiongkok untuk menjadikan AIIB sebagai institusi kelas dunia

${ }^{3}$ Asian Infrastruktire Investment Bank (AIIB), Article of Agreement, pp. 17.

${ }^{54}$ Liam Gennari, pp. 102-105. 
yang nantinya bisa saja semakin menantang eksistensi IFI yang sudah ada seperti ADB.

Selain ADB, Tiongkok juga menantang institusi hasil warisan sistem Bretton Woods yakni IMF dan World Bank yang sering kali dianggap merepresentasikan konsep neoliberalisme dengan AS sebagai hegemonnya. Tiongkok keberatan dengan bagaimana kedua institusi tersebut digunakan untuk memajukan tujuan kepentingan AS dan sekutu-sekutunya. Pinjaman dari World Bank dan IMF dikondisikan dalam disiplin fiskal dan kebijakan lainnya yang disebut Washington Consensus. Kebijakan tambahan lainnya yang juga dipromosikan oleh World Bank adalah lingkungan, hak pekerja, dan pemerintahan yang tidak korup. ${ }^{55}$

Kritik terhadap Konsensus Washington disampaikan oleh Joseph Stiglitz yang berpendapat bahwa pengkondisian yang ditetapkan jauh dari persyaratan yang diberikan oleh bank kepada peminjam untuk memastikan uang itu dibayar kembali dengan bunga. Ia melihat World Bank dan IMF tidak bertindak seperti bank tapi menjadikan instrumen reformasi politik dan ekonomi, sesuai dengan agenda yang ditetapkan oleh AS dan sekutu dekatnya. Sama halnya dengan Stiglitz, Tiongkok juga memiliki keprihatinan terhadap Konsensus Washington. Tiongkok melihat Konsensus Washington sebagai ancaman politik terhadap kepentingan nasional dan global jangka panjang Tiongkok. Konsensus Washington dan doktrin penyesuiannya mendukung pandangan bahwa perdagangan dunia dapat dikondisikan pada serangkaian kebijakan gaya Barat yang diberlakukan oleh negara-negara yang lebih kuat ke negara-negara yang kurang kuat sebagai biaya untuk melakukan bisnis. Sedangkan Tiongkok mengikuti doktrin non intervensi dimana Tiongkok percaya bahwa

\footnotetext{
55 Daniel C.K Chow, Why China Established the Asia Infrastructure Investment Bank, Vanderbilt Journal of Transnational law, Vol. 49:1255, pp. 1277-1278. Diakses melalui: https://www.vanderbilt.edu/jotl/wpcontent/uploads/sites/78/7.-Chow_Paginated.pdf
}

karakteristik politik dari negara peminjam bukanlah urusan siapapun melainkan urusan negara yang meminjam itu sendiri. Dengan berdirinya AIIB, Beijing sekarang memiliki lembaga keuangan multilateral yang mendukung doktrin non intervensi sebagai penyeimbang pendekatan kondisional Washington dalam World Bank dan IMF. Doktrin non intervensi Tiongkok ini dikenal sebagai Beijing Consensus. ${ }^{56}$ Dukungan untuk doktrin non intervensi ini tercantum dalam pasal 31 (2) yang menyatakan bahwa:

"Bank, its President, officers and staff shall not interfere in the political affairs of any member, nor shall they be influenced in their decisions by the political character of the member concerned. Only economic considerations shall be relevant to their decisions. ${ }^{57}$

Selain itu juga tidak ada satupun ketentuan AIIB yang mengacu pada HAM atau hak pekerja.

Beberapa negara di Asia cenderung merespon positif pembentukan AIIB dengan ikut bergabung kedalamnya. Respon positif ini mencerminkan tumbuhnya pengaruh Tiongkok di Asia. Namun resistensi terhadap pembentukan AIIB ternyata datang dari AS. Baginya, pendirian AIIB bernuansa geopolitik dan dianggap sebagai kekuatan lunak Tiongkok untuk menyaingi hegemoni AS yang selama ini didiktekan lewat World Bank dan IMF. Karena itu, AS mendesak negara-negara sekutunya untuk tidak bergabung ke dalam AIIB. Namun harapan AS tidak menjadi kenyataan dimana negara-negara Eropa justru menyatakan dukungan terhadap pendirian AIIB. $^{58}$

Terdapat paradoks menarik jika melihat relasi antara AS dan Tiongkok pada saat ini. Jika dibandingkan dengan rivalitas antara AS dan Uni Soviet pada masa perang dingin

\footnotetext{
${ }^{56}$ Daniel C.K Chow, pp. 1278-1285.

${ }^{57}$ Asian Infrastruktire Investment Bank (AIIB), Article of Agreement, pp. 18.

${ }^{58}$ Humphrey Wangke, pp. 5-6.
} 
dimana masing-masing negara secara terbuka menyatakan bahwa terdapat benturan kepentingan dan pesan permusuhan diantara keduanya. Namun berbeda ketika berhadapan dengan Tiongkok, AS di satu sisi menjadikan Tiongkok sebagai mitra strategis dalam kerjasama ekonomi namun disisi lain AS melihat Tiongkok sebagai ancaman bagi hegemoni keamanan maupun ekonominya. Paradoks ini terlihat dalam bagaimana Obama menyatakan bahwa kebijakan "Pivot to Asia" AS bukan bertujuan membendung pengaruh Tiongkok di Asia. ${ }^{59}$ Begitupula dengan bagaimana Tiongkok melihat AS dimana Tiongkok terus menyatakan bahwa kebijakan BRI tidak akan pernah berusaha menantang hegemoni AS namun BRI hanya sebagai suatu inisiatif yang akan melengkapi kerjasama yang sudah ada. Kedua negara ini tentu menyembunyikan agenda atau kepentingan dibalik kebijakan yang dikeluarkannya.

Berdasarkan penjabaran tersebut maka penulis melihat bahwa salah satu faktor dikeluarkannya kebijakan BRI karena Tiongkok berusaha untuk menjadi hegemon baik itu di bidang keamanan maupun ekonomi.

\section{Kesimpulan}

Belt and Road Initiative (BRI) merupakan salah satu kebijakan ekonomi ambisius yang dikeluarkan Tiongkok pada masa pemerintahan Xi Jinping pada tahun 2013. BRI mencakup dua aspek yaitu the Silk Road Economic Belt dan the 21st Century Maritime Silk Road yang kemudian disingkat Belt and Road. Tujuan dikeluarkannya BRI yaitu untuk menghubungkan ekonomi Eurasia dengan infrastruktur, perdagangan, dan investasi. Namun dibalik tujuan tersebut, Tiongkok sebenarnya memiliki beberapa agenda lain dalam mengeluarkan kebijakan tersebut. Berikut 3 faktor yang mendorong Tiongkok membuat kebijakan BRI menurut neorealisme yaitu: Pertama, kepentingan nasional Tiongkok dalam mengamankan jalur pasokan

${ }^{59}$ M. Najeri Al Syahrin, pp. 151. energi yang menghubungakan Tiongkok ke Timur Tengah sekaligus mencari sumber energi alternatif di Asia Tengah. Asumsi ini terbukti dari kerjasama yang dilakukan Tiongkok dengan Pakistan lewat proyek infrastruktur seperti jalan raya, jalur kereta api, dan pipa gas, serta keputusan Pakistan memberikan kontrol dan manajemen operasional pelabuhan Gwadar di lautan Arabia kepada perusahaan Tiongkok, menawarkan akses ke Teluk Persia dan seluruh kawasan Timur Tengah. Kedua, karena ambisi Tiongkok dalam mengambil alih peran kepemimpinan di kawasan yang terlihat dari usaha menyebarluaskan pengaruhnya lewat proyek kereta cepat yang kemudian bersaing dengan Jepang. Sebagian besar negara-negara yang ada di kawasan Asia menyambut positif proyek Tiongkok sehingga dapat menjadi indikasi bahwa Tiongkok berhasil meningkatkan pengaruhnya. Ketiga, BRI sebagai upaya Tiongkok dalam membangun hegemoni baik itu di bidang keamanan maupun ekonomi. Di bidang keamanan, Tiongkok berusaha membentuk tatanan keamanan baru dengan mengajak negeranegara di kawasan untuk mengeluarkan AS dari urusan keamanan Asia. Sedangkan di bidang ekonomi, Tiongkok membentuk AIIB yang kemudian menantang institusi yang telah lama dibangun AS yaitu World Bank dan IMF maupun IFI yang sudah ada seperti ADB.

\section{Daftar Pustaka}

Arase, David. (2015). China's Two Silk Roads: Implications for Southeast Assia. Singapura: ISEA Perspective.

Asian Infrastructure Investment Bank: Homepage. https://www.aiib.org/en/index.html

Asian Infrastruktire Investment Bank (AIIB). Article of Agreement. https://www.aiib.org/en/aboutaiib/basic- 
documents/_download/articles-ofagreement/basic_document_englishbank_articles_of_agreement.pdf

Asrudin, Azwar. (2014). Thomas Kuhn dan Teori Hubungan Internasional: Realisme Sebagai Paradigma. Indonesian Journal of International Studies (IJIS) 1, 2.

Bhagawati, Jyotishman. (2016). Japan's Grand Strategy to Counter China: An Analysis of the "Partnership for Quality Infrastructure. New Delhi: Institute of Chinese Strudies (ICS). http://www.icsin.org/uploads/2016/08/2 2/6b23d4cc33b9cfe11c7a41ca13c81600 .pdf

Brugier, Camille. (2014). China's way: the New Silk Road. European Union Institute for Security Studies. https://www.iss.europa.eu/sites/default/f iles/EUISSFiles/Brief_14_New_Silk_R oad.pdf

Burchill, Scott. (2005). The National Interest in International Relations Theory. New York: Palgrave Macmillan.

C.K, Daniel Chow. Why China Established the Asia Infrastructure Investment Bank. Vanderbilt Journal of Transnational law. https://www.vanderbilt.edu/jotl/wpcontent/uploads/sites/78/7.Chow_Paginated.pdf

Cai, Peter. (2017). Understanding China's Belt and Road Initiative. Lowy Institute For International Policy. https://www.lowyinstitute.org/sites/defa ult/files/documents/Understanding\%20 China\%E2\%80\%99s\%20Belt\%20and\% 20Road\%20Initiative_WEB_1.pdf

Cha, Changhoon. (2017). China's Westward March: Strategic Views of One Belt One Road. The Korean Journal of International Studies 15, 3.
Chan, Gerald. (2016). China's High-Speed Rail Diplomacy: Global Impacts and East Asian Responses. East Asia Institute.

https://www.eai.or.kr/data/bbs/eng_repo rt/2016021517332269.pdf

Chernoff, Fred. (2007). Theory and Metatheory in International Relations. New York: Palgrave Macmillan

Claudio, Passalacqua Christopher. Chinas's New Opening Up Policy: The One Belt One Road Initiative. LUISS. http://tesi.eprints.luiss.it/17970/1/62510 2_PASSALACQUA_CLAUDIO\%20C HR.pdf

Cruz, Renato De Castro. (2016). The Challenge of Conflict Resolution in the South China Sea Dispute: Examining the Prospect of a Stable Peace in East Asia. International Journal of China Studies 7, 1.

Ebihara, Abubakar. (2011). Pengantar Analisa Politik Luar Negeri: dari Realisme sampai Konstruktivisme. Bandung: Nuansa.

Ekman, Alice. (2016). China's Rise: the View From South Korea. European Union Institute for Security Studies (EUISS). https://www.iss.europa.eu/sites/default/f iles/EUISSFiles/Alert_19_China_ROK. pdf

Gennari, Liam. (2017). Power Transition and International Institution: China's Creation of the Asian Infrastructure Investment Bank. University of Pennsylvania.

http://repository.upenn.edu/cgi/viewcont ent.cgi?article $=1025 \&$ context=ppe_hon ors

Gudetti, Alain. (2015). The Silk Road, Sand Castles and the US-China Rivalry, Geneva Centre for Security Policy 
(GCSP). http://www.gcsp.ch/NewsKnowledge/Publications/The-Silk-

Road-Sand-Castles-and-the-US-ChinaRivalry

Hardoko, Ervan. (2016). Inilah 10 Kereta Api Tercepat di Dunia. kompas.com. http://internasional.kompas.com/read/20 16/09/06/17400981/inilah.10.kereta.api. tercepat.di.dunia?page $=$ all

Hidayat, Taufik. (2015). Revolusi High Speed Rail (Bagian 6). http://majalahka.com/revolusi-highspeed-rail/ http://rinslab.com/wpcontent/uploads/2017/05/Michael_Shee han_The_Balance_of_Power_History_a n_BookFi.pdf

Hwang, Balbina. (2017). What South Korea Thinks of China's 'Belt and Road'. https://thediplomat.com/2017/01/whatsouth-korea-thinks-of-chinas-belt-androad/

Jackson, Robert, dan Georg Sorensen. (2013). Pengantar Hubungan Internasional Teori dan Pendekatan. Yogyakarta: Pustaka Pelajar

Kameda, Masaaki. (2015). Abe Announces $\$ 110$ Billion in Ais for 'High-Quality' Infrastructure in Asia. The Japan Times. https://www.japantimes.co.jp/news/201 5/05/22/business/abe-announces-110billion-in-aid-for-high-qualityinfrastructure-in-asia/\#.WfneKjufLIU

Ker, Michelle. (2017). China's High-Speed Rail Diplomacy. U.S-China Economic and Security Review Commission. https://www.uscc.gov/sites/default/files/ Research/China\%27s\%20High\%20Spee d\%20Rail\%20Diplomacy.pdf

Kertini, Indriana. (2015). Kebijakan Jalur Sutra Baru Cina dan Implikasinya bagi
Amerika Serikat: Jurnal Kajian Wilayah 6, 2

Lin, Yatang, dkk. (2015). International Technology Transfer and Domestic Innovation: Evidence from the HighSpeed Rail Sector in China. The London School of Political Science (LSE). http://cep.lse.ac.uk/pubs/download/dp13 93.pdf

Ma, Damien. 2011. China's Long, Bumpy Road to High-Speed Rail. The Atlantic. https://www.theatlantic.com/internation al/archive/2011/03/chinas-long-bumpyroad-to-high-speed-rail/73192/

Marbler, Penelope, dkk. (2017). Chinese Investments in Infrastructure Worldwide, Institut De Relations Interationales Et Strategiques (IRIS). Asia Focus 36 dalam Asia Programme. http://www.iris-france.org/wpcontent/uploads/2017/06/Asia-Focus36.pdf

Najeri, M. Al Syahrin. (2018). China Versus Amerika Serikat : Interpensi Rivalitas Keamanan Negara Adidaya Di Kawasan Asia Pasifik. Global \& Strategis. Th. 12 No. 1.

Sheehan, Michael. (1996). The Balance of Power History and Theory. New York: Routledge.

Smith, Jeff. (2014). Cold Peace: China-India Rivalry in the Twenty-First Century. Lanham: Lexington Books

The Economist. China Faces Resistance to a Cherished Theme of its Fereign Policy. $4 \quad$ Mei 2017. https://www.economist.com/news/china /21721678-silk-routes-are-not-alwaysappealing-they-sound-china-facesresistance-cherished-theme 
Umana, Felipe. (2012). Transnational Security Threats in the Straits of Malacca, Washington, D.C: The Fund for Peace. http://library.fundforpeace.org/library/tt cvr1213-threatconvergencemalaccastraits-08e.pdf

Wangke, Humphrey. (2015). Penguatan Pengaruh Tiongkok di Kawasan Asia Yilmaz, Sait. (2010). State, Power, and Hegemony. International Journal of Business and Social Science. Vol. 1 No. 3. Terdapat dalam: http://ijbssnet.com/journals/Vol._1_No. _3_December_2010/20.pdf

Yunita, Primadiana. Pemilihan Kazakhstan sebagai Mitra Kerjasama China dalam Sektor Energi Minyak tahun 20032010. Jurnal Ilmiah Transformasi Global 2, 2

Zhidong, Li, dkk., Energy Demand and Supply Outlook in China for 2030 and a Noetheast Asian Energy CommunityThe Automobile Strategy and Nuclear Power Strategy of China-. http://eneken.ieej.or.jp/en/data/pdf/300. pdf

Ziro, Mwatela, Raphael dan Zhao Changfeng. (2016). Africa in China's One Belt One Road Initiative: A Critical Analysis. IOSR Journal of Humanities and Social Science 21, 2 Ver 1 . http://iosrjournals.org/iosrjhss/papers/Vol.\%2021\%20Issue12/Ver sion-1/B2112011021.pdf
Pasifik Melalui Pembentukan AIIB. Info Singkat Hubungan Internasional.

World Bank. GDP Ranking.
https://data.worldbank.org/data-
catalog/GDP-ranking-table

